\title{
Effects of long-term flue gas exposure on chemical- structural properties of South African coals: perspective on advanced analytical techniques
}

Major Mabuza ( $\nabla$ majorm@vut.ac.za )

Vaal University of Technology https://orcid.org/0000-0001-5315-6496

Kasturie Premlall

Tshwane University of Technology

Michael O. Daramola

University of Pretoria

\section{Research}

Keywords: Greenhouse Gases, Flue Gas, Unmineable Coal Seams, Chemical Structural Properties, Advanced Analytical Techniques

Posted Date: October 29th, 2021

DOI: https://doi.org/10.21203/rs.3.rs-1019888/v1

License: (c) (i) This work is licensed under a Creative Commons Attribution 4.0 International License. Read Full License 


\title{
Effects of long-term flue gas exposure on chemical-structural properties of South African coals: perspective on advanced analytical techniques
}

\author{
Major Mabuza ${ }^{1,2, *} \cdot$ Kasturie Premlall ${ }^{2} \cdot$ Michael O. Daramola $^{3}$ \\ ${ }^{1}$ Department of Chemical Engineering, Faculty of Engineering and Technology, Vaal University of Technology, P.O. Box \\ 3595, Secunda 2302, South Africa \\ ${ }^{2}$ Department of Chemical, Metallurgical and Materials Engineering, Faculty of Engineering and the Built Environment, \\ Tshwane University of Technology, Private Bag X680, Pretoria 0001, South Africa \\ ${ }^{3}$ Department of Chemical Engineering, Faculty of Engineering, Built Environment and Information Technology, \\ University of Pretoria, Hatfield 0028, Pretoria, South Africa
}

*Corresponding author: majorm@vut.ac.za

\begin{abstract}
The sequestration of carbon dioxide $\left(\mathrm{CO}_{2}\right)$ in unmineable coal seams is one of the geologic options earmarked to alleviate the emissions of the greenhouse gases to the atmosphere. Direct flue gas injection into unmineable coal seams has been considered to partially offset the cost of the utilizing this technology. This paper presents findings of the evolution of chemical structural properties of two South African coals from Somkhele (Coal SML) and Ermelo (Coal EML) coalfields after long-term (2 232 hours) flue gas exposure by applying advanced analytical techniques. The two coal samples were exposed to a synthetic flue gas simulating coal-fired power plant gas emissions containing $12 \% \mathrm{CO}_{2}, 5.5 \% \mathrm{O}_{2}, 82 \% \mathrm{~N}_{2}$, $0.38 \% \mathrm{SO}_{2}$, and $0.12 \% \mathrm{NO}_{2}$ under in-seam temperature and pressure conditions of $60{ }^{\circ} \mathrm{C}$ and $9.0 \mathrm{MPa}$, respectively. The advanced analytical techniques applied included universal attenuated total reflectance-Fourier transform infrared (UATRFTIR), carbon-13 solid state nuclear magnetic resonance spectroscopy $\left({ }^{13} \mathrm{C}{ }^{\text {ss }} \mathrm{NMR}\right)$, and field emission scanning electron microscopy with energy dispersive X-ray spectroscopy (FESEM-EDX) wide-angle X-ray diffraction (WAXRD). The UATR-FTIR spectra revealed weakened $\mathrm{C}-\mathrm{H}$, aliphatic $\mathrm{C}-\mathrm{C}, \mathrm{C}-\mathrm{O},-\mathrm{OH}$, and out-of-plane aromatic $\mathrm{C}-\mathrm{H}$ functional groups. The results from the treated coals of ${ }^{13} \mathrm{C}{ }^{\text {ss }} \mathrm{NMR}$ for the structural parameters show notable changes in the oxygen functionalities reporting the aliphatic carbon bonded to oxygen, $f_{a l}^{O}$, while the WAXRD data showed some significant changes in the inter-layer spacing and the crystalline diameter as compared to the untreated coals.
\end{abstract}

Keywords Greenhouse Gases; Flue Gas; Unmineable Coal Seams; Chemical Structural Properties; Advanced Analytical Techniques

\section{Introduction}

Sequestration of Carbon dioxide $\left(\mathrm{CO}_{2}\right)$ in unmineable coal seams has been considered one of the most attractive opportunities for mitigating the anthropogenic greenhouse gas emissions (Dutta and Zoback 2012). The end course of the carbon sequestration technology in geological formations is to ensure safe and secure long-term $\mathrm{CO}_{2}$ storage as well as long-term stabilization of the storage site (Tcvetkov et al. 2019). However, $\mathrm{CO}_{2}$ sequestration in unmineable coal seams is a complex occurrence due to the complex structure of coal; as a result, not many researchers have explored the long-term fate of $\mathrm{CO}_{2}$ through the various trapping mechanisms in the coal seams, its distribution within the coal matrix, and longterm site stabilization post- $\mathrm{CO}_{2}$ injection (Estublier et al. 2014). In the framework of direct industrial flue gas injection in unmineable coal seams, there is currently no knowledge of long-term storage that has yet been reported in literature as well as the flue gas-coal long-term interaction under in-seam conditions of temperature and pressure. Most of the flue gas sequestration related studies reported are based on sorption isotherms measurements and data correlation between individual gas sorption capacity and coal rank (Mazumder et al. 2006; Mazumder et al. 2008; Shojai Kaveh et al. 2012; Syed et al. 2013).

In a comparative study by Mazumder et al. (2006) based on custom flue gas $\left(10.9 \% \mathrm{CO}_{2}, 0.01 \% \mathrm{CO}, 3.01 \% \mathrm{CH}_{4}, 0.106 \%\right.$ $\mathrm{SO}_{2}, 3.0 \% \mathrm{O}_{2}$, and $82.974 \% \mathrm{~N}_{2}$ ) and pure $\mathrm{CO}_{2}$ sorption properties of Silesian Basin coal from Poland conducted at $80{ }^{\circ} \mathrm{C}$ and up to a maximum of $11 \mathrm{MPa}$ using volumetric method, it was found that, the sorption of $\mathrm{CO}_{2}$ onto the coal is not significantly hindered by the addition other gases, other than the effect of reducing the $\mathrm{CO}_{2}$ partial pressure of sorption. However, the study did not explore different temperature ranges and, in producing the custom flue gas, the NOx was omitted which are an essential component of a flue gas from a coal-fired power plant. Similar studies were also done by Syed et al. (2013) as well as Durucan and Shi (2009); however, their multicomponent gas was more of binary gas rather than flue gas, since their feed stream only contained $\mathrm{CO}_{2}$ and $\mathrm{N}_{2}$ on average percentage concentrations of $13 \%$ for $\mathrm{CO}_{2}$ and 
$87 \%$ for $\mathrm{N}_{2}$. Binary gas injection could be a good start in multicomponent sorption investigations; however, they do not provide a true reflection of actual flue gas stream (Lukhele et al. 2017).

The understanding of flue gas-coal interaction during direct flue gas sequestration in unmineable coal seams requires advanced analytical techniques to probe the chemical structural properties. These properties include surface chemistry, morphology, and crystallinity of the coal (Mabuza et al. 2020). This paper presents insight into the behaviour of the coal specifically evaluating the chemical structural property changes upon long-term (2 232 hours) exposure to a synthetic industrial flue gas from a typical coal-fired power plant. The structural characterization of two South African coals from Ermelo (Coal EML) and Somkhele (Coal SML) coalfields after long-term flue gas exposure was examined using universal attenuated total reflectance-Fourier transform infrared (UATR-FTIR), carbon-13 solid state nuclear magnetic resonance spectroscopy $\left({ }^{13} \mathrm{C}{ }^{\text {ss }} \mathrm{NMR}\right)$, field emission scanning electron microscopy equipped with energy dispersive $\mathrm{X}$-ray spectroscopy (FESEM-EDX), wide-angle X-ray diffraction (WAXRD).

\section{Experimental}

\subsection{Origin of the coal samples}

Two coal samples were investigated, these coals were acquired from two different South African coalfields, that is, Ermelo (Coal EML) and Somkhele (Coal SML) as shown in Fig. 1. These coals were selected based on their coal rank and coal maceral compositions. In addition, these coalfields have been earmarked as potential future $\mathrm{CO}_{2}$ storage sites as stated by Viljoen et al. (2010) in the "Technical Report on the Geological Storage of Carbon Dioxide in South Africa" published by the South African Council for Geoscience. To avoid excess exposure to the atmosphere and prevent spontaneous oxidation, the samples were placed inside airtight zip-lock bags, flushed with nitrogen gas, and then stored in a refrigerator $\left(<3{ }^{\circ} \mathrm{C}\right.$ temperature condition) as recommended by Ören and Şensöğüt (2018).

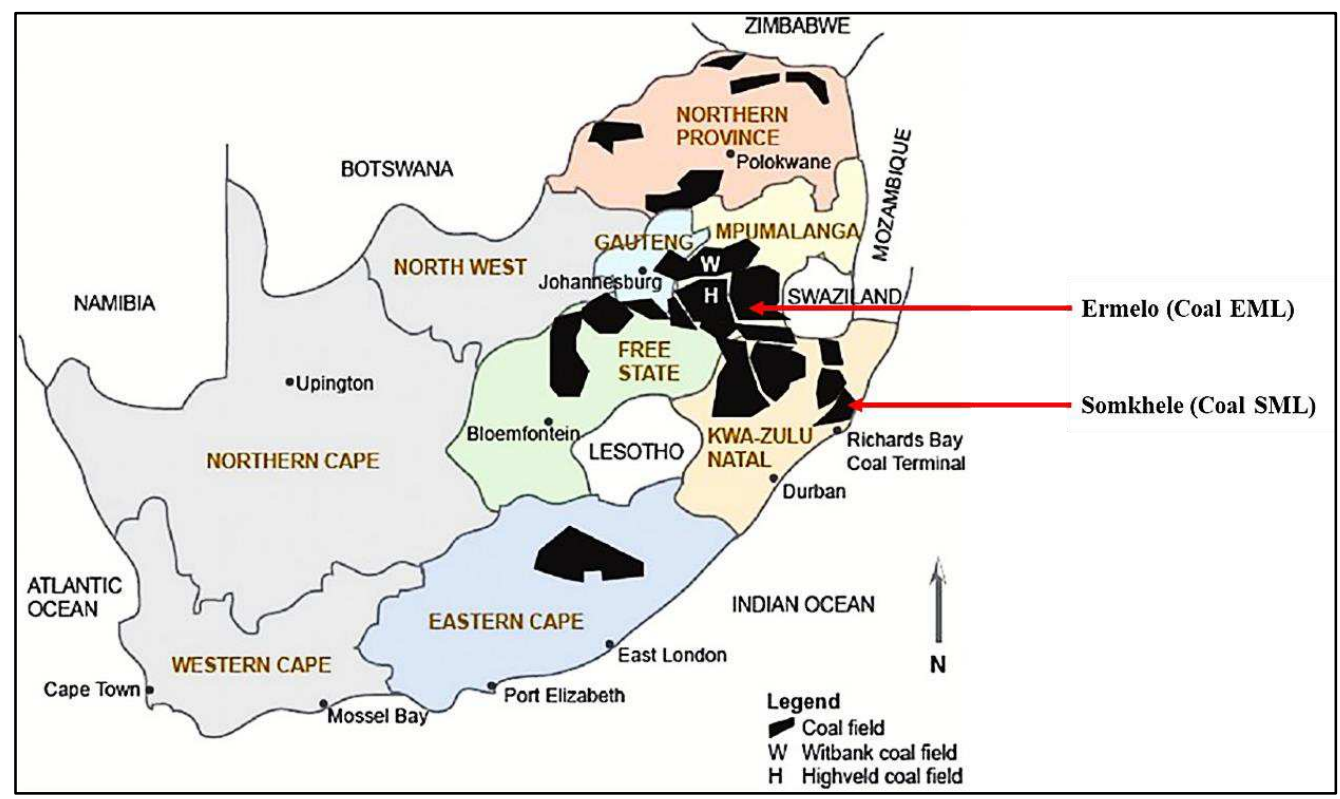

Fig. 1 Map Showing the Location of the South African Coalfields (Lusilao-Makiese et al. 2012)

\subsection{Sample preparation}

Each sample was obtained as $50 \mathrm{~mm}$ lumps and was divided using the coning and quartering method according to ISO 14780 - solid biofuels - sample preparation (2017). It was then crushed with a TENCAN - XPC jaw crusher to an average grain size of $2 \mathrm{~mm}$. These samples were used for flue gas sorption experiments. As a result, a portion of each processed sample was milled using a Retsch Planetary - PM 400 MA-type ball mill to obtain grain size 100\% passing $75 \mu \mathrm{m}$ screen for characterization purposes. For standard properties (proximate and ultimate analysis) a ground coal sample $100 \%$ passing

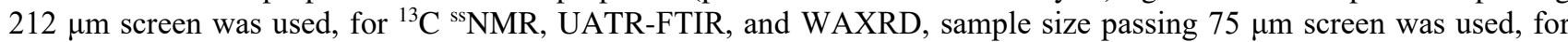
petrographic analysis a sample size passing $1 \mathrm{~mm}$ screen was used, and a sample of $2 \mathrm{~mm}$ average size was used for the FESEM-EDX analysis. In this paper, the standard and petrographic properties of the coals are presented for coal identification and classification purposes; thus, they were not further investigated after flue gas exposure. 


\subsection{Flue gas sorption experiments}

The sorption experiments were conducted using a high-pressure volumetric sorption system (HPVSS) fabricated and verified by Premlall et al. (2019) and following an experimental procedure described by Mabuza et al. (2018). The sorption experiments were conducted at $9.0 \mathrm{MPa}$ and $60{ }^{\circ} \mathrm{C}$ using a synthetic flue gas consisting of $\mathrm{CO}_{2} / \mathrm{O}_{2} / \mathrm{N}_{2} / \mathrm{SO}_{2} / \mathrm{NO}_{2}$ at molar ratio 12:5.5:82:0.38:0.12 as an adsorbate. The coal samples were subjected to the synthetic flue gas under the stated conditions of temperature and pressure for 232 hours. The temperature of $60{ }^{\circ} \mathrm{C}$ corresponds to the coal reservoir depth $(>800 \mathrm{~m})$ and temperature $\left(>31.1^{\circ} \mathrm{C}\right)$ which is regarded adequate for $\mathrm{CO}_{2}$ sequestration as reported by $\mathrm{Zhang}(2008)$.

\section{Results and discussion}

\subsection{Standard properties and petrography}

Table 1 presents the standard properties of the two coals, which include the density measurements, proximate and ultimate analyses, and the petrographic analysis data. Densities of 1.72 and $1.84 \mathrm{~g} / \mathrm{cm}^{3}$ were measured for Coal EML and Coal SML, respectively. Coal EML contain almost $50.0 \mathrm{wt} \%$ of volatile matter as per the proximate analysis data, while Coal SML yielded very low of the same component at 7.6\%. The inherent moisture of Coal EML is 4.5 wt.\% and that of Coal SML is $1.0 \mathrm{wt} . \%$. The fixed carbon yield is low for Coal EML at $\sim 28.0 \mathrm{wt} . \%$, and high for Coal SML at $\sim 73.0 \mathrm{wt} . \%$. The coals' intrinsic moisture content varied from 1.1 to $4.5 \mathrm{wt} . \%$, and the ash content was almost the same at $18.0 \mathrm{wt} . \%$. Coal EML and Coal SML have carbon content yields of $75.0 \mathrm{wt} . \%$ and $90.0 \mathrm{wt} \%$, respectively, according to the ultimate analysis data. The total sulphur concentration and hydrogen concentration are low for both coals, ranging from $4.04-4.63$ wt. $\%$, and $0.61-0.73$ wt. $\%$, respectively, while the nitrogen concentrations are comparable for both coals at $\sim 1.9$ wt. $\%$. The oxygen concentration of the coals was found by calculation to range from $3.06-17.82 \mathrm{wt} . \%$.

Table 1 Standard properties and petrographic analysis of the coal samples

\begin{tabular}{|c|c|c|c|c|}
\hline \multirow[t]{2}{*}{ Analysis Type } & \multicolumn{2}{|c|}{ Sample ID } & \multirow[t]{2}{*}{ ISO Method } & \multirow{2}{*}{ Reference } \\
\hline & Coal EML & Coal SML & & \\
\hline Density $\left(\mathrm{g} / \mathrm{cm}^{3}\right.$, ar $)$ & 1.72 & 1.84 & N/A & \\
\hline \multicolumn{5}{|l|}{ Proximate Analysis (wt.\%, adb) } \\
\hline Moisture & 4.5 & 1.0 & $11722: 2013$ & (ISO 2013b) \\
\hline Ash & 17.9 & 17.3 & 1171:2010 & (ISO 2010b) \\
\hline Volatile Matter & 49.8 & 7.6 & $562: 2010$ & (ISO 2010a) \\
\hline Fixed Carbon & 27.8 & 74.1 & By difference & \\
\hline \multicolumn{5}{|l|}{ Ultimate Analysis (wt.\%, daf) } \\
\hline Carbon & 75.1 & 82.0 & $17247: 2013$ & (ISO 2013a) \\
\hline Hydrogen & 4.6 & 3.1 & $17247: 2013$ & (ISO 2013a) \\
\hline Nitrogen & 1.9 & 1.9 & $17247: 2013$ & (ISO 2013a) \\
\hline Oxygen & 17.8 & 12.1 & $17247: 2013$ & (ISO 2013a) \\
\hline Sulphur* & 0.6 & 0.9 & 19579:2006 & (ISO 2006) \\
\hline \multicolumn{5}{|l|}{ Petrographic Analysis } \\
\hline RoV\% & $0.64(0.097)^{* *}$ & $2.24(0.434)^{* *}$ & 7404:2009 & (ISO 2009) \\
\hline Rank & Medium Rank C & High Rank C & 11760:2018 & (ISO 2018) \\
\hline Type & Bituminous C & Anthracite C & 11760:2018 & (ISO 2018) \\
\hline \multicolumn{5}{|l|}{ Maceral Analysis (V\%, inc. mm) } \\
\hline Total Vitrinite (TV) & 12.8 & 84.0 & 11760:2018 & (ISO 2018) \\
\hline Total Inertinite (TI) & 74.2 & 11.5 & 11760:2018 & (ISO 2018) \\
\hline Total Liptinite (TL) & 3.3 & 0 & 11760:2018 & (ISO 2018) \\
\hline Total Mineral Matter (TMM) & 9.8 & 4.5 & 602:2015 & (ISO 2015) \\
\hline Total Reactive Macerals (TRM) & 25.6 & 84.0 & By summation & \\
\hline
\end{tabular}

daf - dry ash free basis, adb - air dried basis, ar - as received, *total sulphur, **Standard deviation, $\mathrm{R}_{\mathrm{O}} \mathrm{V}=$ mean vitrinite random reflectance, inc. mm including mineral matter, TRM $=\mathrm{TL}+\mathrm{TV}+$ Inertodetrinite + Reactive semifusinite. 
Petrographic analysis data presented in Table 1 show that Coal EML and Coal SML have mean vitrinite random reflectance $\left(\mathrm{R}_{\mathrm{o}}\right)$ of 0.64 vol.\% and 2.24 vol.\%, respectively. Based on the $\mathrm{R}_{\mathrm{o}}$ results, Coal EML is classified as medium rank C (bituminous C) while Coal SML is high rank C (Anthracite C). Coal EML is inertinite-rich (74.2 vol.\%, inc. mm), while Coal SML is vitrinite-rich $(84.0$ vol. $\%$, inc. $\mathrm{mm})$. The petrographic analysis results further reveal that Coal SML has a higher content of reactive macerals when compared to Coal EML.

\subsection{Chemical-structural properties}

\subsubsection{Surface chemistry (UATR-FTIR and $\left.{ }^{13} C^{s s} N M R\right)$}

The UATR-FTIR spectra for untreated and flue gas treated Coal EML and Coal SML are presented in Fig. 2. The peaks of the two coals have been identified and observed to slightly change and in some regions significantly change after flue gas exposure. This implies that the chemical structure for both coals changed as the flue gas exposure was prolonged when probed with UATR-FTIR. The IR absorbance for majority of the peaks remain unchanged from the original spectra and no new peaks appeared after flue gas treatment; however, there are changes in the percentage transmittance of the peaks. The most obvious changes observed have been marked with an orange oval shape for each region.
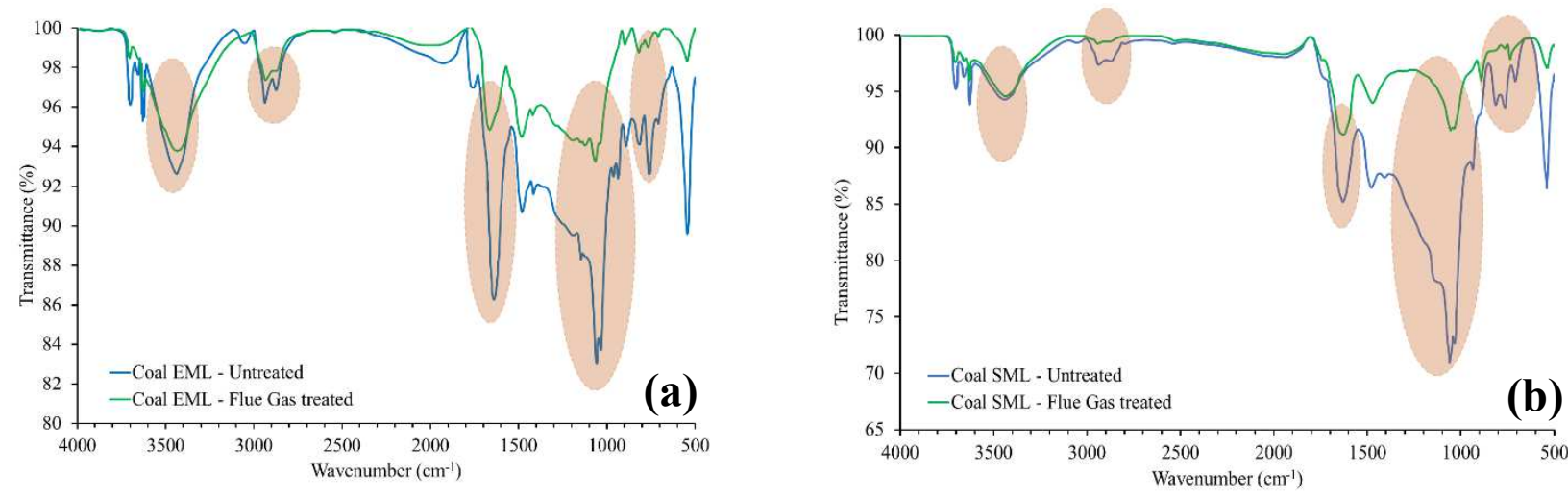

Fig. 2 UATR-FTIR spectra of flue gas treated and untreated: (a) Coal EML and (b) Coal SML

The UATR-FTIR spectra broad region, $3700-3100 \mathrm{~cm}^{-1}$, which is assigned to - $\mathrm{OH}$ stretching vibrations, responded differently after flue gas treatment for Coal SML and Coal EML. The intensity of this region remained high and wide for the inertinite-rich Coal EML possibly due to the high inherent moisture (4.5\%) content. The intensity of this peak gradually reduced over extended flue gas exposure period; this is attributable to the steady moisture vaporization over time at $60{ }^{\circ} \mathrm{C}$ (Wan-xing et al. 2011) showing the decrease in the hydroxyl group and the occurrence of dihydroxylation in the coal samples. The intensity of the broad region for vitrinite-rich Coal SML remained low and wide after long term flue gas exposure implying the presence of the $-\mathrm{OH}$ group due to low inherent moisture $(1.0 \%)$ content. Contrary to Coal EML, this region remained the same as the untreated sample for Coal SML.

The two coals show further weakening in the $\mathrm{C}-\mathrm{H}$ stretching vibrations, $3100-3000 \mathrm{~cm}^{-1}$, after flue gas exposure. This is observable on the spectra by $0 \%$ IR absorbance in this region, and this is more observable in Coal EML spectra. This weakening occurred due to an increase in the degree of condensation of the aromatic rings of the two coals; as a result, causing the two coals to be highly substituted (Yao et al. 2011). The aliphatic $-\mathrm{COOH}$ and $\mathrm{C}=\mathrm{O}$ stretching vibrations region, $1700 \mathrm{~cm}^{-1}$, show no characteristic distinct changes after flue gas exposure for the two coals. This region is proportional to the fraction of carbons bonded to the carbonyls (Wu and Zhang 2019); which remained unchanged after flue gas exposure, especially for low rank Coal EML as per the ${ }^{13} \mathrm{C}{ }^{\text {ss }} \mathrm{NMR}$ results presented in Table 2 . However, the high rank Coal SML was characterized by a slight increase in absorption intensity in this region. This is alluded to the fractional reduction in fraction of carbons bonded to the carbonyls after flue gas exposure of the coal relative to the untreated coal.

The absorption of aromatic stretching vibrations, $1680-1500 \mathrm{~cm}^{-1}$ representing $\mathrm{C}=\mathrm{C}$, did not change after flue gas exposure for the two coals. This could mean that there was no progressive coalification of the coals that took place during the flue gas exposure period (Ibarra et al. 1996). Similar response was observed for the region $1680-1460 \mathrm{~cm}^{-1}$, representing the aromatic stretching vibrations of aromatic rings. The peak in the region $1280-1000 \mathrm{~cm}^{-1}$, representing the aliphatic skeletal $\mathrm{C}-\mathrm{C}, \mathrm{C}-\mathrm{O}$ stretching, and $-\mathrm{OH}$ bending vibrations, show a weakened IR absorption after flue gas exposure relative to untreated coals. This observation is applicable to both coals under investigation. The attribution of this behaviour is systemically based on further weakening of the aliphatic skeletal $\mathrm{C}-\mathrm{O}$ and $\mathrm{C}-\mathrm{C}$ stretching vibrations in the 
phenoxy and phenolic structures. This indicates that the concentration of the phenols in the two coals is very low as presented in the ${ }^{13} \mathrm{C}{ }^{\text {ss }} \mathrm{NMR}$ results in Table 2. This is also alluded to the gradual vaporization of the inherent moisture of the coals; as a result, reducing the existence of the -OH group (Qin et al. 2010). There is a sharp decrease in the IR absorption in the region $900-700 \mathrm{~cm}^{-1}$ after flue gas exposure of the coals, these multiple and small peaks are attributed to the out-of-plane aromatic $\mathrm{C}-\mathrm{H}$ bending vibrations. This is due to the considerable decrease in substituted aromatic - $\mathrm{CH}-\mathrm{CH}$ chains (Shao et al. 2019; Li et al. 2015), which caused a decrease in the number of infrared spectral absorption peaks.

Coal EML and Coal SML nuclear magnetic resonance (NMR) spectra with quantitative carbon-13 cross-polarization magic angle spinning $(13 \mathrm{C}(1 \mathrm{H}) \mathrm{CP}-\mathrm{MAS})$ and dipolar-dephasing magic angel spinning (DD-MAS) are shown in Fig. 3. The figure compares the ${ }^{13} \mathrm{C}{ }^{\text {ss }} \mathrm{NMR}$ spectra of the untreated and flue gas treated coals. The signal to noise ratio remained low for the spectra. The aliphatic regions, aliphatic regions, SSB2, and SSB1 were all observed at the same integral regions of 90-0, 150-90, 60-0, and 255-200 ppm, respectively, for the two coal samples. This implies that there are no apparent alterations brought by the flue gas treatment of the coals. The high intensity of SSB2 for Coal SML after flue gas treatment is alluded to the magical-angle spinning (MAS) rate being less than the chemical shift anisotropy (CSA) frequency range associated with the aromatic carbons.
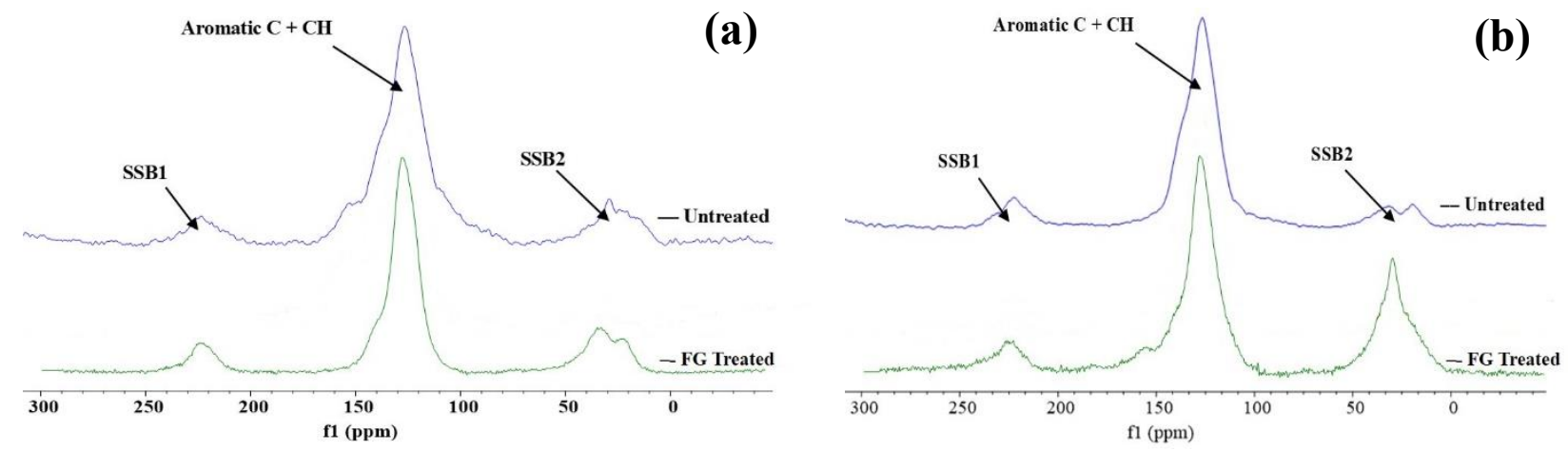

Fig. $3{ }^{13} \mathrm{C}\left({ }^{1} \mathrm{H}\right) \mathrm{CP}-\mathrm{MAS}$ with DD-MAS NMR spectra of flue gas treated and untreated: (a) Coal EML and (b) Coal SML

The aromatic regions of the spectra of the two coals show other notable differences. The aromatic regions maintained the same intensity as the untreated coals; however, the peak area of the regions became slightly narrow after flue gas exposure. This could explain the slight variations in the aromaticity for the coal samples after flue gas exposure. These variations in aromaticity directly affect the aliphatic regions as seen in Table 2 for Coal EML and Coal SML. However, it is suggested that in the current study, the variations in the aromaticity are not due to the period of flue gas exposure but could potentially be a result of the heterogeneous nature of the coals (Yu et al. 2007).

The oxygen functionalities $\left(f_{a l}^{O}, f_{a}^{C O}, f_{a}^{P}\right)$ for both coals did not significantly change after flue gas exposure in comparison to the untreated coals. The most notable change in the oxygen functionalities is the aliphatic carbon bonded to oxygen, $f_{a l}^{O}$, which increased by $\sim 42 \%$ for Coal EML and increased by $\sim 22 \%$ for Coal SML in comparison to the untreated coals. These changes are alluded to the oxygen contained in the flue; as a result, substituting to produce stronger intensities of the $\mathrm{COO}$ and $\mathrm{C}-\mathrm{O}$ bonds (Baysal et al. 2016). Other functionalities including the alkylated aromatic carbons, $f_{a}^{S}$, and non-protonated carbons in the aromatic region, $f_{a}^{N}$, reported negligible changes after flue gas exposure owing to the heterogeneity of the coal structure. 
Table $2{ }^{13} \mathrm{C}$ ss NMR structural parameters (wt.\% of carbons bonded to aliphatic and aromatic carbons) of flue gas treated and untreated Coal EML and Coal SML

\begin{tabular}{|c|c|c|c|c|c|}
\hline \multirow[b]{2}{*}{ Carbon Assignment } & \multirow[b]{2}{*}{$\begin{array}{l}\text { Integral } \\
\text { Region }\end{array}$} & \multicolumn{2}{|c|}{ Coal EML } & \multicolumn{2}{|c|}{ Coal SML } \\
\hline & & Untreated & FG Treated & Untreated & FG Treated \\
\hline Total aromatic carbons, $f_{a}$ & $135-90$ & 0.87 & 0.88 & 0.91 & 0.95 \\
\hline Total aliphatic carbons, $f_{a l}$ & $60-0$ & 0.13 & 0.12 & 0.09 & 0.05 \\
\hline Aliphatic carbons bonded to oxygen, $f_{a l}^{O}$ & $90-60$ & 0.022 & 0.038 & 0.021 & 0.027 \\
\hline Carbons bonded to carbonyls, $f_{a}^{C O}$ & $200-165$ & 0.07 & 0.07 & 0.02 & 0.05 \\
\hline Carbons bonded to phenolics, $f_{a}^{P}$ & $165-150$ & 0.10 & 0.12 & 0.05 & 0.04 \\
\hline Alkylated aromatic carbons, $f_{a}^{S}$ & $150-135$ & 0.16 & 0.17 & 0.15 & 0.13 \\
\hline Non-Protonated carbons in aromatic region, $f_{a}^{N}$ & - & 0.64 & 0.64 & 0.73 & 0.71 \\
\hline Protonated carbons in aromatic region, $f_{a}^{H}$ & - & 0.17 & 0.18 & 0.16 & 0.23 \\
\hline Bridgehead carbons in aromatic region, $f_{a}^{B}$ & - & 0.38 & 0.33 & 0.53 & 0.52 \\
\hline Non-Protonated carbons and methyl groups, $f_{a l}^{N *}$ & - & 0.05 & 0.02 & 0.05 & 0.05 \\
\hline Aliphatic $\mathrm{CH}$ and $\mathrm{CH}_{2}, f_{a l}^{H}$ & - & 0.08 & 0.11 & 0.03 & 0.03 \\
\hline
\end{tabular}

\subsubsection{Crystallinity and morphology (WAXRD and FESEM-EDX)}

The diffractograms of Coal EML and Coal SML are presented in Fig. 4. The diffractograms presented are for the untreated and flue gas treated coals. The patterns of the diffractograms are similar and remained unchanged for both coals when comparing the untreated and flue gas treated coals. The (002) peak position for both Coal EML and Coal SML remained within the original position and unchanged, this could be due to small reduction in elemental carbon content of the coals after flue gas exposure as shown in Table 4. This is more observable in vitrinite-rich Coal SML than inertinite-rich Coal EML.
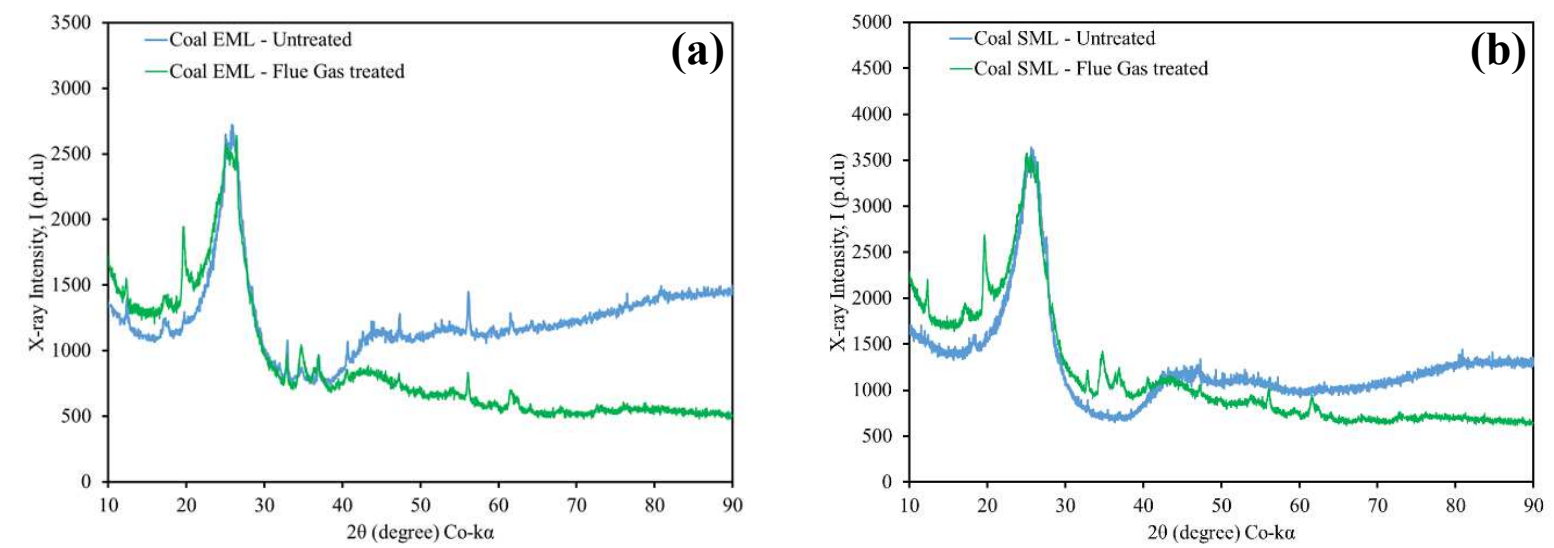

Fig. 4 WAXRD spectra of flue gas treated and untreated: (a) Coal EML and (b) Coal SML

Since there was no enhanced spontaneous combustion that took place in the system, the coal samples still contain amorphous carbons after flue gas exposure, this is indicated by the high intensity background. These amorphous carbons appear in a form graphite-like structure. The peaks at $\sim 26^{\circ}(002)$ and $\sim 43^{\circ}(010)$ result from the occurrence of these crystalline carbons. The flue gas treated coals have saturated structures of aliphatic side chains, this is observed by the retention of the asymmetric $\gamma$-band on the left of the (002) band. Anorthite $\left(\mathrm{CaAl}_{2} \mathrm{Si}_{2} \mathrm{O}_{8}\right)$ and pyrite $\left(\mathrm{FeS}_{2}\right)$ crystals remained present in the coals after long-term flue gas treatment, this is revealed by the existence of small and narrow peaks beyond (010) band. This is consistent with the results obtained by EDX presented in Table 4 with the occurrence of kaolinite, quartz, and pyrite on the coals after flue gas exposure.

Table 3 present the structural parameters for the untreated and flue gas treated Coal EML and Coal SML. It is observed from the calculated structural properties that there are no major changes after flue gas treatment. Even so, there is a trend observed in two structural properties (inter-layer spacing and crystalline height) of the two coals which seem to be affected 
by the period of flue gas exposure. However, there is no definitive trend identified for the crystalline height since the calculated values show fluctuations.

The inter-layer spacing of the coals reported a decrease after flue gas exposure. This resulted in a decrease of $15 \%$ and $22.8 \%$ relative to untreated Coal EML and Coal SML, respectively. This structural deformation is adsorption-induced due to the high-pressure strain created by the flue gas, as a result, causing crystalline interlayer spacings to contract. A similar relative comparison reported an increase of $37.5 \%$ and $17.3 \%$ in crystalline diameter for Coal EML and Coal SML, respectively. According to Schaeperkoetter et al. (2019) this increase indicates successful incorporation of the gas molecules within the carbon crystals during the high-pressure adsorption process.

Table 3 WAXRD structural parameters of flue gas treated and untreated Coal EML and Coal SML

\begin{tabular}{|c|c|c|c|c|}
\hline \multirow[t]{2}{*}{ Sample ID } & \multicolumn{2}{|c|}{ Coal EML } & \multicolumn{2}{|c|}{ Coal SML } \\
\hline & Untreated & FG treated & Untreated & FG treated \\
\hline \multicolumn{5}{|c|}{ Structural parameters acquired from the X'Pert Highscore Plus software and WAXRD spectra } \\
\hline Wavelength - $\lambda(\AA)$ & 1.51 & 1.51 & 1.51 & 1.51 \\
\hline $2 \theta\left({ }^{\circ}\right)$ & 26.40 & 26.68 & 26.57 & 27.12 \\
\hline$\beta_{002}-\mathrm{FWHM}$ at 002 band & 0.90 & 0.97 & 0.14 & 0.2115 \\
\hline$\beta_{10}-\mathrm{FWHM}$ at 10 band & 0.63 & 0.44 & 0.12 & 0.146 \\
\hline Scherrer's Constant $-K_{c}$ at 002 band (-) & 0.89 & 0.89 & 0.89 & 0.89 \\
\hline Scherrer's Constant $-K_{a}$ at 10 band (-) & 1.84 & 1.84 & 1.84 & 1.84 \\
\hline \multicolumn{5}{|c|}{ Bragg's and Scherrer's laws structural properties } \\
\hline Inter-layer spacing $-d_{002}(\AA)$ & 1.27 & 1.08 & 1.14 & 0.88 \\
\hline Crystalline height $-L_{c}(\AA)$ & 1.84 & 1.93 & 12.46 & 12.13 \\
\hline Crystalline diameter $-L_{a}(\AA)$ & 5.44 & 8.70 & 30.06 & 36.33 \\
\hline Aromatic layers per carbon crystalline $-N_{\text {ave }}(-)$ & 2.45 & 2.79 & 11.89 & 14.74 \\
\hline Aromaticity, $f_{a}(-)$ & 0.84 & 0.86 & 0.87 & 0.92 \\
\hline
\end{tabular}

The micrographs acquired from the FESEM of untreated and flue gas treated Coal EML and Coal SML are presented in Fig. 5 and Fig. 6, respectively. It is observed that the coal samples are not uniform due to the heterogeneity of the coals. The morphology of the coals was not expected to be altered after flue gas exposure. Hence, the coals maintained their heterogeneous nature as observed in Fig. 5 (b) and Fig. 6 (b), with the coals having uneven and irregular surfaces with indefinite-shaped crystals as the untreated coals.

Table 4 presents the elemental results of the Coal EML and Coal SML, obtained from the EDX analysis. The results are presented as normalized and the elements in ppm levels were undetectable. The mineralogical results of the two coals show a decrease in carbon content (graphite form) after flue gas exposure relative to untreated coals. As a result, a few mineral impurities, including $\mathrm{Al}$ (kaolinite), $\mathrm{P}$ (apatite), and $\mathrm{Si}$ (quartz), emerged and increased in concentration. This means that these mineral impurities were present in the untreated; however, due to the dominance and high concentration of graphite they could not be detected by the EDX analysis. 

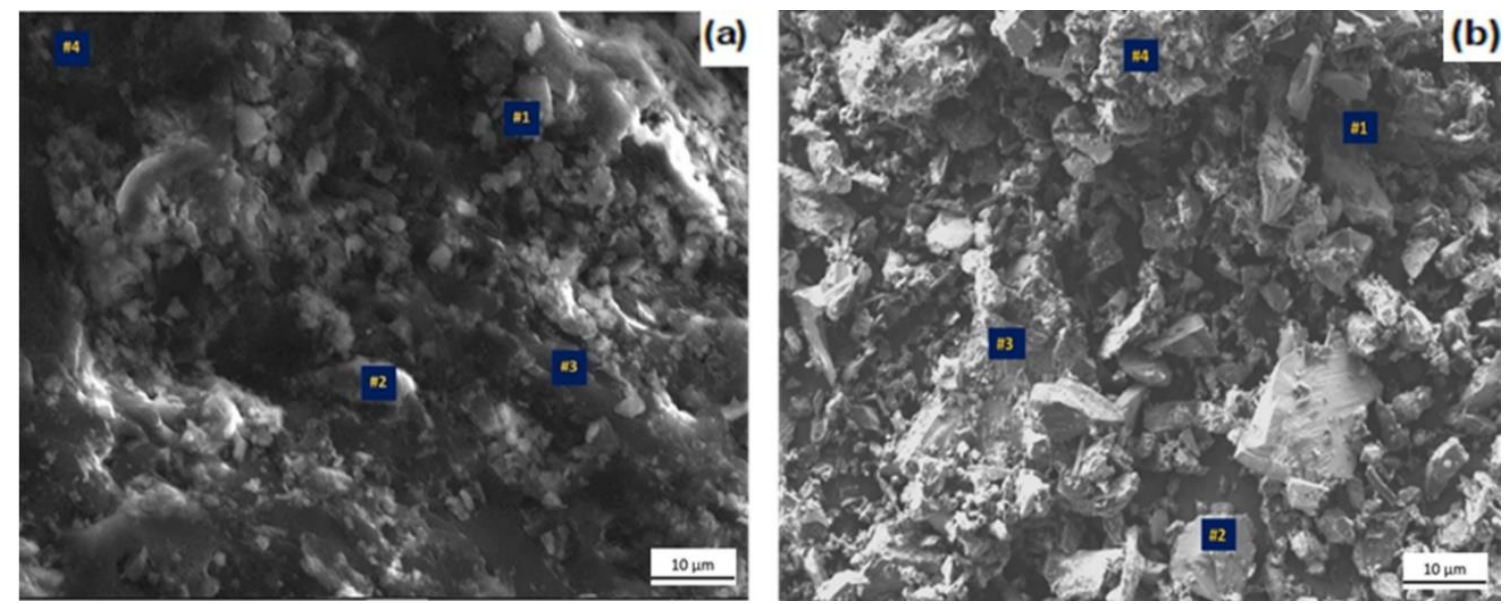

Fig. 5 FESEM micrographs of Coal EML: (a) untreated and (b) flue gas treated
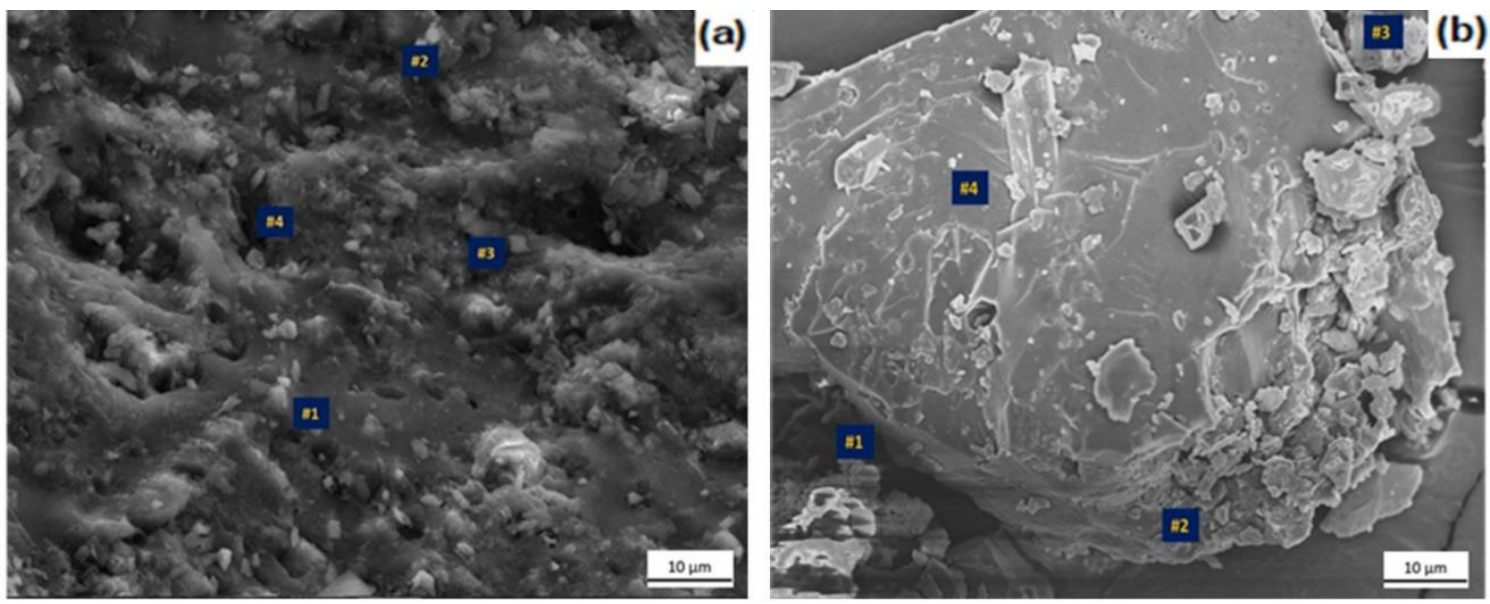

Fig. 6 FESEM micrographs of Coal SML: (a) untreated and (b) flue gas treated

For Coal EML, the carbon concentration reduced by $11 \%$ after flue gas exposure relative to untreated coal. For Coal SML, a reduction of $17 \%$ was reported. Consequently, for Coal EML, the concentration of the mineral impurities kaolinite, quartz, and apatite increased by $46.3 \%, 0.7 \%$, and $52.5 \%$, respectively, after flue gas exposure relative to untreated coal. The respective order for Coal SML is $45.8 \%, 32.3 \%$, and $100 \%$ relative to untreated coal.

Table 4 Normalized weight percentages of elemental composition acquired by EDX for flue gas treated and untreated (ST and LT) Coal EML and Coal SML.

\begin{tabular}{|c|c|c|c|c|c|}
\hline \multirow[b]{3}{*}{ Element } & \multicolumn{2}{|c|}{ Coal EML } & \multicolumn{2}{|c|}{ Coal SML } & \\
\hline & Untreated & FG treated & Untreated & FG treated & \\
\hline & Weight $\%$ & Weight $\%$ & Weight $\%$ & Weight $\%$ & Possible form of Mineral \\
\hline $\mathrm{C}$ & 65.79 & 58.7 & 80.68 & 66.94 & graphite \\
\hline $\mathrm{O}$ & 14.56 & 18.19 & 12.20 & 15.71 & - \\
\hline $\mathrm{Na}$ & 0 & 0 & 0 & 0 & Na-Al-silicate \\
\hline $\mathrm{Mg}$ & 0 & 0 & 0 & 0 & dolomite \\
\hline $\mathrm{Al}$ & 2.20 & 4.1 & 1.43 & 2.64 & kaolinite \\
\hline $\mathrm{Si}$ & 7.06 & 7.11 & 3.79 & 5.60 & kaolinite/quartz \\
\hline $\mathrm{P}$ & 10.40 & 8.6 & 0 & 7.70 & apatite \\
\hline $\mathrm{S}$ & 0 & 3.3 & 1.90 & 1.41 & gypsum/pyrite \\
\hline Total & 100 & 100 & 100 & 100 & \\
\hline
\end{tabular}


As observed in this study, coal analysis with FESEM-EDX alone does not give strong and understandable chemicalstructural changes of the coals after gas treatment. However, when FESEM-EDX analysis is combined with the WAXRD, UATR-FTIR, and ${ }^{13} \mathrm{C}{ }^{\mathrm{ss}} \mathrm{NMR}$ analyses, a clear distinction is established (Ramesh and Somasundaran 1990). As a result, some researchers (Cheng et al. 2017; Kolak and Burrus 2005; Maphala 2012; Okolo 2017; Xie 2015) did not include FESEM-EDX concept in their studies due to this encounter. However, these researchers mainly focused on pure $\mathrm{CO}_{2}$ exposure on coals. This study focuses on flue gas exposure on coals instead of pure $\mathrm{CO}_{2}$; thus, exploring possible chemicalstructural changes of the coals by FESEM-EDX analysis combined with the WAXRD, UATR-FTIR, and ${ }^{13} \mathrm{C}{ }^{\mathrm{ss}} \mathrm{NMR}$ analyses was necessary.

\section{Conclusions}

After flue gas treatment at a pressure and temperature of $9.0 \mathrm{MPa}$ and $60^{\circ} \mathrm{C}$, respectively, for 2232 hours, various advanced analytical methods were effectively employed to evaluate the chemical-structural properties of two South African coal samples. Thereafter, a comparative study was done between the untreated (as received) and flue gas treated coals to investigate the degree of these chemical structural changes.

The UATR-FTIR spectra revealed weakened peaks for most of the functional groups after long-term flue gas exposure in comparison to the untreated. The most noticeable weakened functional groups include the $\mathrm{C}-\mathrm{H}\left(3100-3000 \mathrm{~cm}^{-1}\right)$, aliphatic $\mathrm{C}-\mathrm{C}, \mathrm{C}-\mathrm{O},-\mathrm{OH}\left(1280-1000 \mathrm{~cm}^{-1}\right)$, and out-of-plane aromatic $\mathrm{C}-\mathrm{H}$. The oxygen functionalities $\left(f_{a}^{C O}, f_{a}^{P}\right)$, alkylated aromatic carbon, $f_{a}^{S}$, and non-protonated carbons in the aromatic region, $f_{a}^{N}$, obtained through the ${ }^{13} \mathrm{C}^{\mathrm{ss}} \mathrm{NMR}$ analysis show to have negligible changes after long-term flue gas exposure in comparison to untreated coals. The most notable change in the oxygen functionalities is the aliphatic carbon bonded to oxygen, $f_{a l}^{o}$, which increased by $\sim 42 \%$ for Coal EML and by $\sim 22 \%$ for Coal SML comparing to the untreated coals.

WAXRD derived results showed some significant changes in the inter-layer spacing and the crystalline diameter of the coals after the long-term flue gas exposure. The inter-layer spacing of the coals decreased after flue gas exposure, while the crystalline diameter increased after flue gas exposure. This resulted in a decrease of $15 \%$ and $22.8 \%$ relative to untreated Coal EML and Coal SML, respectively. A similar relative comparison reported an increase of 37.5\% and $17.3 \%$ in crystalline diameter for Coal EML and Coal SML, respectively. The EDX-derived quantitative elemental composition data found that the graphite concentration for Coal EML and Coal SML reduced by $11 \%$ and 17\%, respectively, after long term flue gas exposure relative to untreated. Consequently, for Coal EML, the concentration of the mineral impurities kaolinite, quartz, and apatite reported an increase of up to $92.7 \%$, and for Coal SML this increase was up to $100 \%$.

\section{Availability of data and materials}

The raw data that support the findings of this study may be made available by the corresponding upon request.

\section{Competing interests}

The authors declare that none of the material in the paper has been published or is in the process of being published elsewhere, and that there are no conflicting interests.

\section{Acknowledgements}

The authors would like to acknowledge the financial support provided by the National Research Foundation (NRF) of South African. Any findings, opinions and conclusions derived from this material are those of the authors and do not represent the NRF.

\section{References}

Baysal M, Yürüm A, Yıldız B, Yürüm Y (2016) Structure of some western Anatolia coals investigated by FTIR, Raman, 13C solid state NMR spectroscopy and X-ray diffraction. Int J Coal Geol 163(1):166-176. https://doi.org/10.1016/j.coal.2016.07.009

Cheng Y, Jiang H, Zhang X, Cui J, Song C, Li X (2017) Effects of coal rank on physicochemical properties of coal and on methane adsorption. International Journal of Coal Science \& Technology 4(2):129-146. 10.1007/s40789-017$0161-6$ 
Durucan S, Shi J-Q (2009) Improving the $\mathrm{CO}_{2}$ well injectivity and enhanced coalbed methane production performance in coal seams. International Journal of Coal Geology 77(1):214-221. https://doi.org/10.1016/j.coal.2008.09.012

Dutta P, Zoback MD (2012) $\mathrm{CO}_{2}$ sequestration into the Wyodak coal seam of Powder River Basin-Preliminary reservoir characterization and simulation. Int J Greenh Gas Con 9(1):103-116. https://doi.org/10.1016/j.ijggc.2012.03.004

Estublier A, Bachaud P, Michel A, Maurand N, Deflandre JP (2014) Long-term fate of $\mathrm{CO}_{2}$ in a saline aquifer: modeling issues. Enrgy Proced 63(1):3464-3474. https://doi.org/10.1016/j.egypro.2014.11.375

Ibarra J, Muñoz E, Moliner R (1996) FTIR study of the evolution of coal structure during the coalification process. Organic Geochemistry 24(6):725-735. http://dx.doi.org/10.1016/0146-6380(96)00063-0

ISO (2006) Solid mineral fuels — Determination of sulfur by IR spectrometry, in ISO 19579. Geneva, Switzerland: International Organization for Standardization

ISO (2009) Methods for the petrographic analysis of coals - Part 5: Method of determining microscopically the reflectance of vitrinite, in ISO 7404-5. Geneva, Switzerland: International Organization for Standardization

ISO (2010a) Hard coal and coke - Determination of volatile matter, in ISO 562. Geneva, Switzerland: International Organization for Standardization

ISO (2010b) Solid mineral fuels - Determination of ash, in ISO 1171. Geneva, Switzerland: International Organization for Standardization

ISO (2013a) Coal - Ultimate analysis, in ISO 17247. Geneva, Switzerland: International Organization for Standardization

ISO (2013b) Solid mineral fuels - Hard coal - Determination of moisture in the general analysis test sample by drying in nitrogen, in ISO 11722. Geneva, Switzerland: International Organization for Standardization

ISO (2015) Coal - Determination of mineral matter, in ISO 602:2015. Geneva, Switzerland: International Organization for Standardization

ISO (2017) Solid biofuels - Sample preparation, in ISO 14780. Geneva, Switzerland: International Organization for Standardization

ISO (2018) Classification of coals, in ISO 11760:2018. Geneva, Switzerland: International Organization for Standardization

Kolak JJ, Burrus RC (2005) The effect of coal rank on the physicochemical interactions between coal and $\mathrm{CO}_{2}$-implications for $\mathrm{CO}_{2}$ storage in coal beds. In: Rubin ES, Keith DW, Gilboy CF, Wilson M, Morris T, Gale J, Thambimuthu K (ed) Greenhouse Gas Control Technologies 7. Oxford, Elsevier Science Ltd

Li X, Zeng FG, Wang W, Dong K, Cheng LY (2015) FTIR characterization of structural evolution in low-middle rank coals. J China Coal Soc 40(12):2900-2908. https://doi.org/10.13225/j.cnki.jccs.2015.1085

Lukhele K, D, Premlall K, Shongwe M, Mabuza M, M, Daramola M, O (2017) Effect of $\mathrm{SO}_{2}$ co-feeding on $\mathrm{CO}_{2}$ adsorption capacity of South African coals during $\mathrm{CO}_{2}$ sequestration. Petroleum and Coal 59(2):177-186.

Lusilao-Makiese J, Tessier E, Amouroux D, Tutu H, Chimuka L, Cukrowska EM (2012) Speciation of mercury in South African coals. Toxicol Environ Chem 94(9):1688-1706. https://doi.org/10.1080/02772248.2012.728604

Mabuza M, Premlall K, Daramola MO (2020) Physicochemical characterization of South African coals upon short-term flue gas exposure using conventional and advanced techniques. Mater Sci Energy Technol 3(1):25-35. https://doi.org/10.1016/j.mset.2019.09.008

Mabuza M, Premlall K, Onyango M, Daramola M, O (2018) Low-high temperature flue gas direct injection in South African bituminous and anthracite coals: sorption capacity assessment. Current Science 115(4):682-691. $10.18520 / \mathrm{cs} / \mathrm{v} 115 / \mathrm{i} 4 / 682-691$

Maphala T (2012) Effects of Carbon Dioxide Storage in Coal on the Physical and Chemical Properties of Coal. Dissertation, University of the Witwatersrand

Mazumder S, Van Hemert P, Busch A, Wolf KHA, Tejera-Cuesta P (2006) Flue gas and pure $\mathrm{CO}_{2}$ sorption properties of coal: A comparative study. Int J Coal Geol 67(4):267-279. http://dx.doi.org/10.1016/j.coal.2005.12.001

Mazumder S, Wolf KHA, Van Hemert P, Busch A (2008) Laboratory Experiments on Environmental Friendly Means to Improve Coalbed Methane Production by Carbon Dioxide/Flue Gas Injection. Transport Porous Med 75(1):6392. https://doi.org/10.1007/s11242-008-9222-z

Okolo GN (2017) Adsorption properties of South African bituminous coals relevant to carbon dioxide storage. Dissertation, North-West University

Ören Ö, Şensöğüt C (2018) Determination of Safe Storage Types for Coals with Regard to Their Susceptibility to Spontaneous Combustion - Tuncbilek Coal Case. International Journal of Coal Preparation and Utilization 38(6):290-301. 10.1080/19392699.2016.1252339

Premlall K, Mabuza M, M, Potgieter J, H (2019) Design, construction and performance reliability verification evaluation of a high pressure volumetric sorption system for $\mathrm{CO}_{2}$ sorption in South African coals. Petroleum and Coal 61(4):813-835.

Qin S, Wang J, Zhao C, Zhang S (2010) Long-Term, Low Temperature Simulation of Early Diagenetic Alterations of Organic Matter: A FTIR Study. Energy Exploration \& Exploitation 28(5):365-376.

Ramesh R, Somasundaran P (1990) SEM/EDX Studies on Association of Mineral Matter in Coal. Coal Preparation 8(12):93-99. 10.1080/07349349008905175 
Schaeperkoetter JC, Connolly MJ, Buck ZN, Taub H, Kaiser H, Wexler C (2019) Adsorption-Induced Expansion of Graphene Oxide Frameworks: Observation by in Situ Neutron Diffraction. ACS omega 4(20):18668-18676. 10.1021/acsomega.9b02589

Shao P, Wang A, Wang W (2019) Effect of chemical structure of lignite and high-volatile bituminous coal on the generation of biogenic coalbed methane. Fuel 245(1):212-225. https://doi.org/10.1016/j.fuel.2019.02.061

Shojai Kaveh N, Wolf KH, Ashrafizadeh SN, Rudolph ESJ (2012) Effect of coal petrology and pressure on wetting properties of wet coal for $\mathrm{CO}_{2}$ and flue gas storage. Int $\mathrm{J}$ Greenh Gas Con 11(1):91-101. https://doi.org/10.1016/j.ijggc.2012.09.009

Syed A, Durucan S, Shi J-Q, Korre A (2013) Flue Gas Injection for $\mathrm{CO}_{2}$ Storage and Enhanced Coalbed Methane Recovery: Mixed Gas Sorption and Swelling Characteristics of Coals. Enrgy Proced 37(1):6738-6745. http://dx.doi.org/10.1016/j.egypro.2013.06.607

Tcvetkov P, Cherepovitsyn A, Fedoseev S (2019) Public perception of carbon capture and storage: A state-of-the-art overview. Heliyon 5(12):e02845. https://doi.org/10.1016/j.heliyon.2019.e02845

Viljoen J, H, A, Stapelberg F, D, J, Cloete M (2010) Technical Report on the Geological Storage of Carbon Dioxide in South Africa. In: Downes G, van der Spuy D, van Eck S, van Heerden A (ed). Silverton, Pretoria, RSA, Council for Geoscience

Wan-Xing R, Zeng-Hui K, De-Ming W (2011) Causes of Spontaneous Combustion of Coal and Its Prevention Technology in The Tunnel Fall of Ground of Extra-thick Coal Seam. Procedia Engineer 26(1):717-724. https://doi.org/10.1016/j.proeng.2011.11.2228

Wu D, Zhang W (2019) Evolution Mechanism of Macromolecular Structure in Coal during Heat Treatment: Based on FTIR and XRD In Situ Analysis Techniques. J. Spectrosc 2019(1):1-18. https://doi.org/10.1155/2019/5037836

Xie K-C (2015) Physical Characteristics of Coal. Berlin, Germany, Sringer-verlag

Yao S, Zhang K, Kun J, Hu W (2011) Evolution of coal structures: FTIR analyses of experimental simulations and naturally matured coals in the Ordos Basin, China. Energy Exploration \& Exploitation 29(1):1-19.

Yu D, Xu M, Zhang L, Yao H, Wang Q, Ninomiya Y (2007) Computer-Controlled Scanning Electron Microscopy (CCSEM) Investigation on the Heterogeneous Nature of Mineral Matter in Six Typical Chinese Coals. Energy \& Fuels 21(2):468-476. 10.1021/ef060419w

Zhang Q-L (2008) Adsorption mechanism of different coal ranks under variable temperature and pressure conditions. Journal of China University of Mining and Technology 18(3):395-400. http://dx.doi.org/10.1016/S1006$\underline{1266(08) 60083-8}$ 